\title{
LYMPHOID/NONLYMPHOID COMPARTMENTALIZATION OF DONOR LEUKOCYTE CHIMERISM IN RAT RECIPIENTS OF HEART ALLOGRAFTS, WITH OR WITHOUT ADJUNCT BONE MARROW ${ }^{1}$
}

\author{
Masanobu Terakura, ${ }^{2}$ Noriko Murase, ${ }^{2,3}$ Anthony J. Demetris, ${ }^{4}$ QIng Ye, ${ }^{2}$ \\ Angus W. ThOMson, ${ }^{2}$ and ThOMAS E. STARZL ${ }^{2}$ \\ Departments of Surgery and Pathology, Thomas E. Starzl Transplantation Institute, \\ University of Pittsburgh Medical Center, Pittsburgh, Pennsylvania 15213
}

\begin{abstract}
Background. The role of leukocyte migration and chimerism in organ allograft acceptance has been obscured by the lack of information about the late localization of the donor cells.

Methods. Male Lewis rat $\rightarrow$ female Brown Norway abdominal heart transplantation was performed under tacrolimus immunosuppression (days $0-13,20$, and 27) with or without donor bone marrow and (in bone marrow subgroups) a 1-week postoperative course of a possibly chimerism-enhancing drug. Using rat sexdetermining region-Y-specific oligonucleotide primers, we determined the donor DNA concentration by polymerase chain reaction in serial venous blood samples for 100 days and in tissue specimens when animals were killed.
\end{abstract}

Results. Chimerism was detected out to 56 days in $89 \%$ of the blood samples but in none of the samples at 100 days. However, donor DNA was detected when animals were killed in $95 \%$ of the native hearts, $80 \%$ of the skin biopsy specimens, and $23 \%$ of the spleens. The presence and quantity of early and late chimerism were strongly correlated the administration of adjunct bone marrow and with a reduction in the vasculopathy and inflammation index in the cardiac allografts. Marginally significant further increases in chimerism and/or reductions in chronic heart rejection beyond those achieved with adjunct bone marrow alone were associated with additional treatment with the growth factors Flt-3 ligand, granulocyte colonystimulating factor, and a recombinant molecular variant of interleukin-6 (interleukin-6 mutein) but not with hepatocyte growth factor or lisofylline.

Conclusions. The previously suspected shift of early chimerism in the blood and lymphoid organs to dominance in host nonlymphoid tissues is consistent with the dual mechanisms of clonal exhaustion and immune indifference, governed by antigen migration and localization, that have been postulated elsewhere to account for organ allograft acceptance.

Widespread activation of the recipient immune system is induced peripherally by the migration of donor leukocytes

\footnotetext{
${ }^{1}$ This work was supported by grants from the American Heart Association, Pennsylvania Affiliate, and NIH grants DK 29961 and AIDK38899-01A2.

${ }^{2}$ Department of Surgery.

${ }^{3}$ Address correspondence to: Noriko Murase, MD, Department of Surgery, Thomas E. Transplantation Institute, BST E1555, University of Pittsburgh, Pittsburgh, PA 15213. E-mail: murase+@ @itt.edu.

${ }^{4}$ Department of Pathology.
}

from the graft to host lymphoid organs via vascular routes (1-4), including pluripotent stem cells $(5,6)$. Although it was long assumed that the donor leukocytes were promptly destroyed by the recipient immune system as a prerequisite for successful organ transplantation, their more complex role was recognized with the discovery that they persisted peripherally (microchimerism) and eventually were widely dispersed to host nonlymphoid (e.g., skin $[7,8]$ and heart [9]) as well as lymphoid sites.

The migration kinetics involved in the transition from a lymphoid-oriented donor leukocyte traffic to a more ubiquitous distribution and the eventual proportions in lymphoid versus nonlymphoid areas have not been determined. Filling this informational void out to 100 days was the primary objective of the experiments reported herein, using the rat heterotopic heart transplantation model, with or without adjunct donor bone marrow cell infusion. In an attempt to further augment the increased chimerism, subgroups of heart recipients given adjunct bone marrow were also treated with one of four hematolymphopoietic growth factors or with the phosphatidic acid inhibitor lisofylline.

\section{MATERIALS AND METHODS}

\section{Animals and Transplant Procedures}

Heart transplantation. Male Lewis (LEW*; RT1 ${ }^{1}$ ) and female Brown Norway (BN; $\mathrm{RT}^{\mathrm{n}}$ ) rats weighing $150-200 \mathrm{~g}$ (Harlan Sprague Dawley, Indianapolis, IN) were used as donors and recipients, respectively. The use of sex-mismatched allografts allowed estimation of the level of chimerism after transplantation with a probe specific for sex-determining region $\mathrm{Y}$ ( $\mathrm{Y}$ chromosome). The male LEW heart grafts were transplanted heterotopically into the abdomen of female BN recipients (10).

Adjunct bone marrow infusion. Male LEW bone marrow cells were obtained by flushing the tibias and femurs. The irrigating fluid was processed with RPMI 1640 medium supplemented with $25 \mathrm{mM}$ HEPES buffer, $2 \mathrm{mM} \mathrm{L}$-glutamine, and $10 \mu \mathrm{g} / \mathrm{ml}$ gentamicin (all from Life Technologies, Grand Island, NY). Bone marrow cells $\left(2.5 \times 10^{8}\right.$ cells/animal) with $>95 \%$ viability in the trypan blue exclusion test were injected intravenously into the jugular vein of female recipients on the day of heart transplantation.

\section{Immunosuppression and Hematopoietic Growth Factors}

Tacrolimus. All recipients received $1.5 \mathrm{mg} / \mathrm{kg}$ intramuscular tacrolimus per day (Fujisawa Pharmaceutical Co., Ltd., Osaka, Japan)

* Abbreviations: BN, Brown Norway; G-CSF, granulocyte colonystimulating factor; IL, interleukin; LEW, Lewis; PCR, polymerase chain reaction; Sry, sex-determining region $\mathrm{Y}$. 
on days 0 to 13 after transplantation with additional single injections on days 20 and 27 . With this model, hearts have prolonged survival, but at 100 days, the allografts frequently have histopathologic evidence of chronic rejection $(10,11)$.

Growth factors. As shown in Table 1, the conventional growth factors tested were the following: rh-granulocyte colony-stimulating factor (G-CSF, $200 \mu \mathrm{g} / \mathrm{kg} /$ day; Amgen, Thousand Oaks, CA), Chinese hamster ovary cell-derived rh-Flt-3 ligand ( $200 \mu \mathrm{g} / \mathrm{kg} /$ day; a gift from Immunex, Seattle, WA) (12), interleukin (IL)-6 mutein, a recombinant molecular variant of human IL-6 $(500 \mu \mathrm{g} / \mathrm{kg} /$ day, a gift from ImClone System Inc., Somerville, NJ) (13), and rr-hepatocyte growth factor $(200 \mu \mathrm{g} / \mathrm{kg} / \mathrm{day}$, a gift from Pharmaceutical Research Center, Toyobo Co., Ohtsu, Japan). In addition, the effect of the phosphatidic acid inhibitor lisofylline $(150 \mathrm{mg} / \mathrm{kg} / \mathrm{day}$, a gift from Cell Therapeutic Inc., Seattle, WA) was determined (14). The daily doses, routes, and frequency of injection during the 7-day course (days 0-6) are shown in Table 1.

All reagents have been confirmed to be active in rats. Although a detailed dose-effectiveness experiment was not conducted in this study, the dosage and route for each molecule were determined from published recommendations $(15,16)$ or according to information from the supplier. In general, dosages that were confirmed to produce specific biologic effects of each molecule in rats were selected, and molecules with short half-lives were administered twice daily and those with relatively long half-lives (IL-6 and Flt-3 ligand) were administered once daily. To test their comparative biologic activity, the effects on venous hematocrit (tail vein), total leukocytes, and leukocyte subsets (Table 2 ) were determined 7 days after the various transplantation procedures, 1 day after completion of the treatment course. Flow cytometry was performed using monoclonal antibodies R7.3 ( $\alpha \beta$-T cell receptor), OX1 (CD45), OX33 (B cells), 3.2.3 (natural killer cells), and ED1 (monocyte/macrophage) (all from Sera-Lab, Crawley Down, UK). The percentage of granulocytes was assessed on a cytocentrifuge preparation stained with $\alpha$-naphthyl acetate esterase (Sigma Diagnostics, St. Louis, MO).

Intergroup hematocrit variances were minor or nonsignificant (data not shown). Although the $\mathrm{BN}$ allograft recipients receiving tacrolimus (all groups 1-7) had lower total leukocyte counts than normal nonoperated animals, this was significantly influenced by growth factor therapy only in the heart transplant/bone marrow recipients treated with IL-6. The most striking finding was an increase in the percentage of granulocytes in allograft recipients treated with lisofylline, Flt-3 ligand, and G-CSF (Table 2). Changes in the subset profile of polymorphonuclear leukocytes attributable specifically to a growth factor (as opposed to the transplant procedure or tacrolimus) were minor except for a near doubling of the percentage of natural killer cells by G-CSF treatment (Table 2).

\section{Pathologic Studies}

At autopsy, graft and native hearts were serially sectioned across both ventricles in the transverse plane. One section from the midportion of the ventricles was fixed in neutral buffered formalin for routine histopathology, and a second similar cross-section was snapfrozen in optimum cold temperature compound (Tissue-Tek, Ames Division, Miles Laboratories, Inc., Elkhart, IN) for immunohistochemical studies. A third cross-section of both donor and recipient hearts and samples from other recipient organs (including the kidney, liver, spleen, thymus, skin, cervical lymph nodes, and bone marrow) were immediately snap-frozen in liquid nitrogen for chimerism analysis with polymerase chain reaction (PCR). Special precau-

TABLE 1. Experimental groups-all transplantations were from male LEW donors to female BN recipients treated with tacrolimus ${ }^{a}$

\begin{tabular}{|c|c|c|c|}
\hline Group & Transplantation $^{b}$ & Drug & Dose/day \\
\hline $0^{c}$ & None & None & NA \\
\hline 1 & $\mathrm{H}$ & None & NA \\
\hline 2 & $\mathrm{H} / \mathrm{BM}$ & None & $\mathrm{NA}$ \\
\hline 3 & $\mathrm{H} / \mathrm{BM}$ & Lisofylline (i.p.) & $150 \mathrm{mg} / \mathrm{kg}^{d}$ \\
\hline
\end{tabular}
Growth factor

NA
NA
NA

Inhibits lysophosphatidic acid acyl transferase and blocks the formation of phosphatidic acid 1- $\alpha$ induced by the stimulation of cytokines, endotoxin, hypoxia-reoxygeneration, and cytotoxic agents; suppresses production of inflammatory and hematopoiesis-inhibiting cytokines (IL-1, IL-6, IFN- $\gamma$, TNF- $\alpha$, TGF- $\beta$, macrophage inhibitory protein $1-\alpha$, and platelet factor 4) (14)

\begin{tabular}{|c|c|c|c|c|}
\hline 4 & $\mathrm{H} / \mathrm{BM}$ & Flt-3 ligand (i.p.) & $200 \mu \mathrm{g} / \mathrm{kg}^{\circ}$ & $\begin{array}{l}\text { Promotes the growth and mobilization of hematopoietic stem cells } \\
\text { and committed precursor cells for multiple myeloid and lymphoid } \\
\text { lineages; dramatically increases the numbers of dendritic cells in } \\
\text { both lymphoid and nonlymphoid tissues (12) }\end{array}$ \\
\hline 5 & $\mathrm{H} / \mathrm{BM}$ & G-CSF (s.c.) & $200 \mu \mathrm{g} / \mathrm{kg}^{d}$ & $\begin{array}{l}\text { Supports the proliferation and differentiation of progenitors already } \\
\text { committed to the neutrophil lineage; also affects all lineages } \\
\text { derivative from stem cells }\end{array}$ \\
\hline 6 & $\mathrm{H} / \mathrm{BM}$ & HGF (i.p.) & $200 \mu \mathrm{g} / \mathrm{kg}^{d}$ & $\begin{array}{l}\text { One of a functionally related group of factors that modulate } \\
\text { hematopoiesis; is a ligand for the c-met proto-oncogene, which is } \\
\text { expressed on epithelial cells as well as hematopoietic progenitor } \\
\text { cells }\end{array}$ \\
\hline 7 & $\mathrm{H} / \mathrm{BM}$ & IL-6 (s.c.) & $500 \mu \mathrm{g} / \mathrm{kg}^{\varepsilon}$ & $\begin{array}{l}\text { Multipotential cytokine that stimulates B- and T-cell differentiation } \\
\text { and primitive hematopoietic stem cell population; IL- } 6 \text { mutein } \\
\text { used in this study lacks } 22 \text { amino acids from the amino terminus } \\
\text { of IL- } 6 \text { and has serine replacements at positions } 74 \text { and } 84 \text {; has } \\
\text { maximum activity at a lower concentrations than native IL-6 (13) }\end{array}$ \\
\hline
\end{tabular}

${ }^{a}$ Intramuscular tacrolimus: $1.5 \mathrm{mg} / \mathrm{kg} /$ day on days $0-13,20$, and 27 .

${ }^{b} \mathrm{H}$, heart; BM, unfractionated bone marrow $2.5 \times 10^{8}$ cells/animal.

${ }^{c}$ Nonoperated and nonimmunosuppressed normal female BN rat.

${ }^{d}$ Twice daily injection of divided dose.

${ }^{e}$ Once daily injection. 
TABLE 2. Effect of hematopoietic growth factors and lisofylline on peripheral blood leukocytes 7 days after transplantation

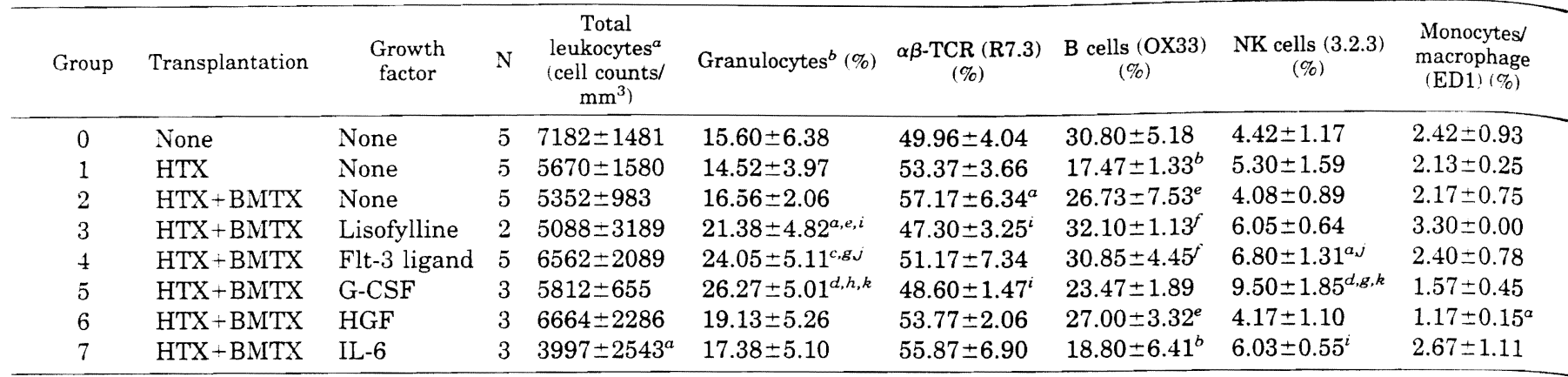

${ }^{a}$ Cells were counted on a hemacytometer.

${ }^{b}$ Granulocytes were determined on blood smear after an $\alpha$-naphthyl acetate esterase stain.

$P$ vs group 0: $a<0.05, b<0.01, c<0.001, d<0.0001$

$P$ vs group 1: $e<0.05, f<0.01, g<0.001, h<0.0001$

$P$ vs group $2: i<0.05, j<0.01, k<0.0001$

tions were taken during sampling not to contaminate female recipient tissues by contact with the male heart graft.

The formalin-fixed heart grafts were embedded in paraffin, sectioned at $4 \mu \mathrm{m}$, and stained with hematoxylin and eosin. All slides were reviewed by one of the authors (A.J.D.) without knowledge of the treatment protocols. The overall severity of inflammation in the endocardium, pericardium, interstitium, and periarterial spaces was graded semiquantitatively on a scale of 0 to 4 as none, minimal, mild, moderate, or severe, as previously described (11). Arterial alterations, including the presence of inflammation, edema, fibrosis, and vacuolation of the intima, media, and adventitia, were graded in the same fashion. In addition, the total numbers of arteries $>80 \mu \mathrm{m}$ present in the cross-section were recorded, to ensure a similar sampling between animals. The grading of obliterative arteriopathy was as follows: none (grade 0 ), $<10 \%$ luminal narrowing (grade 1 ), $10-$ $25 \%$ (grade 2 ), $26-50 \%$ (grade 3 ), $51-75 \%$ (grade 4 ), and $>75 \%$ luminal narrowing (grade 5) (11).

\section{PCR and Southern blot hybridization}

Genomic DNAs were prepared from blood samples and recipient tissues using a standard procedure and quantitated by spectrophotometer (17). The PCR was performed with $1.5 \mu \mathrm{g}$ of genomic DNA in $50 \mu \mathrm{l}$ of total reaction mixture containing 1.25 units of Taq DNA polymerase, $1 \mu \mathrm{l}$ each of $25 \mu \mathrm{M}$ rat sex determining region-Y (Sry)specific oligonucleotide primers (5'-GAGAGAGGCACAAGTTGGC-3' and $5^{\prime}$-GCCTCCTGGAAAAAGGGCC-3'), $8 \mu \mathrm{l}$ of $1.25 \mathrm{mM}$ dNTP, and $5 \mu \mathrm{l}$ of $10 \times$ PCR buffer $(500 \mathrm{mM} \mathrm{KCl}, 20 \mathrm{mM} \mathrm{MgCl} 2,100 \mathrm{mM}$ Tris $\mathrm{HCl}$, and $0.1 \%$ gelatin, adjusted to $\mathrm{pH} 8.4$ ) (18). The PCR was carried out under the following conditions: denaturation at $95^{\circ} \mathrm{C}$ for 60 seconds, annealing at $55^{\circ} \mathrm{C}$ for 45 seconds, and extension at $72^{\circ} \mathrm{C}$ for 2 min for 35 cycles in a DNA thermal cycler. The reaction was then extended for $7 \mathrm{~min}$ at $72^{\circ} \mathrm{C}$ to ensure the production of full-length PCR products.

The PCR products were then fractionated in $1.5 \%$ agarose gels and stained with ethidium bromide. DNA products amplified with Sryspecific primers were also transferred onto nylon membranes for Southern blotting and semiquantitation. The Sry-specific probe was prepared by extraction and purification of PCR product, which was prepared from male LEW spleen DNA, using the QIAEX II gel extraction kit (QIAGEN Inc., Chatsworth, CA). It was also multiprime-labeled with $\alpha{ }^{32} \mathrm{P}$ dCTP $(3000 \mathrm{Ci} / \mathrm{mmol}$, NEN Research Products, Boston, MA) using the multiprime DNA labeling systems (Amersham Life Science, Buckinghamshire, UK). Membranes were prehybridized for $2 \mathrm{hr}$ at $47^{\circ} \mathrm{C}$ in buffer containing saline-sodium phosphate EDTA buffer $(5 \times), 0.1 \%$ sodium dodecyl sulfate, Denhart's solution $(5 \times)$, and $0.1 \%$ SSDNA. The ${ }^{32} \mathrm{P}$-labeled probe was added to hybridization buffer and further incubated for $16 \mathrm{hr}$ at $47^{\circ} \mathrm{C}$. After hybridization, each membrane was washed four times in $1 \times \mathrm{SSPE} / 0.1 \%$ sodium dodecyl sulfate for $5 \mathrm{~min}$ at room temperature and then once in the same solution for $5 \mathrm{~min}$ at $50^{\circ} \mathrm{C}$. Membranes were exposed to Storage Phosphor Screen (Molecular Dynamics, Sunnyvale, CA) for $4 \mathrm{hr}$ at room temperature, and the radioactivity on the screen was measured with the PhosphorImager (Molecular Dynamics).

The level of chimerism in each sample was calculated with a standard curve prepared using known concentrations of male DNA. DNAs were prepared from male LEW and female BN spleens and mixed at various ratios ranging from $1: 10$ to $1: 10^{5}$. Mixtures were amplified with PCR. After Southern hybridization, radioactivities of these mixtures were analyzed by phosphoimaging and the standard curve was created (Fig. 1), with which male DNA concentrations in blood and organs obtained from the female recipients were semiquantified. It was possible to detect the male DNA concentration up to $0.001 \%$ (donor-recipient ratio $=1: 100,000$ ). Donor DNA was considered to be nondetectable when the radioactivity after Southern hybridization of experimental samples was below the value of control females.

\section{Statistical Analysis}

One-way analysis of variance and Fisher's PLSD test were applied to assess the statistical significance of different groups. A value of $P<0.05$ was considered significant.
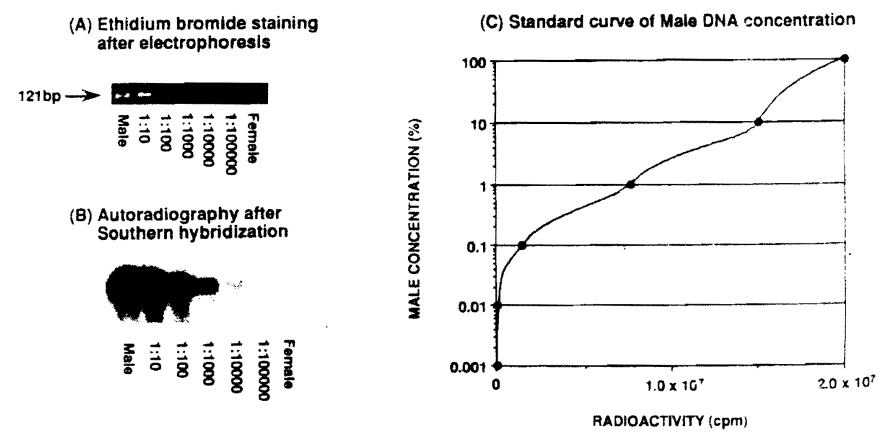

FiguRE 1. Standard curve for the semiquantitation of male DNA concentration in samples. DNAs from male LEW spleen and female $\mathrm{BN}$ spleen were mixed at ratios ranging from $1: 10$ to $1: 10^{-5}$. These mixtures were amplified by PCR using Sry-specific primers. PCR products were (A) separated in $1.5 \%$ agarose gel for ethidium bromide staining and (B) transferred onto nylon membrane for Southern hybridization. After hybridization, radioactivities were analyzed by phosphoimaging and a standard curve was created (C). 
RESULTS

\section{Peripheral Blood Chimerism}

Figure 2 demonstrates the frequency of detection and the concentrations of male DNA in the tail vein blood of the heart recipients $7,14,28,56$, and 100 days after transplantation. Adjunct donor bone marrow infusion was the only treatment variable that increased the detection rate or concentration of the chimerism, with no additional effect of growth factor treatment. In the heart/bone marrow recipients (groups 2-7), the concentration of male DNA reached $1-10 \%$ in the peripheral blood at 7-28 days after transplantation and then decreased slowly to $0.1-1 \%$ at 56 days after transplantation. Donor DNA was not detectable in the peripheral blood of any recipient by 100 days after transplantation, no matter what the treatment regimen.

\section{Tissue Chimerism at 100 Posttransplant Days}

In contrast to the disappearance of blood chimerism, male DNA was found in the following host tissues when the rats were killed: liver, native heart, skin (tongue), spleen, cervical lymph nodes, and bone marrow. The complete results from the spleen samples shown in Figure 3A are representative of the other lymphoid organs (data not shown). The results from the skin and recipient heart (Fig. 3, B and C) typify the pattern in the nonlymphoid sites. Both the frequency of positive samples and the concentrations of donor DNA were higher in the skin and native heart than in the spleen (Fig. 3).

Adjunct donor bone marrow alone (group 2) significantly increased the frequency of detection and concentration of male DNA in all locations assayed, compared with those observed with transplantation of the heart only (group 1) (Fig. 3). Additional treatment with Flt-3 ligand (group 4) was associated with a further increase in male DNA in the spleen $(P=0.0093$, vs. group 2 , Fig. $3 \mathrm{~A})$ and native heart $(P=0.025$, Fig. 3C). IL-6 treatment (group 7) was also associated with a significant increase of male DNA in the recipient native heart compared with group 2 ( $P=0.0402$, Fig. $3 C$ ).

\section{Histopathologic Evaluation of Heart Grafts}

As expected from previous experience with this model $(10,11)$, all 39 heart grafts transplanted heterotopically beat for 100 days. Thirty-seven were available for histopathologic analysis and standardized grading; two grafts, one each from groups 3 and 5, were not analyzed because of an inadequate sample. The overall inflammation score reflects the general alloreactivity in the heart grafts. This score was significantly reduced in all groups in which heart grafts were transplanted simultaneously with donor bone marrow (Table 3 ). The greatest improvement relative to group 1 was with G-CSF, Flt-3 ligand, or IL-6 treatment (Table 3), but this advantage was not statistically significant when compared with the results with adjunct bone marrow alone (group 2).

Obliterative arteriopathy was evaluated in each sample and is expressed as the percentage of arteries showing vasculopathy and as the average grade of the disease seen in 6 to 22 arteries per heart graft. Compared with hearts transplanted alone (group 1), the cardiac allografts transplanted with adjunct bone marrow to recipients also treated with G-CSF (group 5) and IL-6 (group 7) had significant improvement in both categories (Table 3 ).

\section{Histopathologic Correlations with Chimerism}

The autopsy samples from all the cardiac allografts of groups 1-7 were pooled and the histopathologic changes were correlated with the pooled levels of chimerism in the native hearts of these same animals. The native hearts were selected as the chimerism reference because donor DNA was found in $>90 \%$ of these specimens (see Fig. 3C).

The scattergrams in Figure 4 demonstrate the correlation between the concentration of chimerism and the average grade of arterial lesions (Fig. 4A), percentages of diseased arteries (Fig. 4B), and overall inflammation (Fig. 4C). Despite strong trends, there was no statistically significant linear relationship between the average histopathologic grades of arterial lesions and chimerism $\left(R^{\wedge} 2=0.098\right.$, $P=0.0594$; Fig. 4A) or percentages of diseased arteries $\left(\mathrm{R}^{\wedge} 2=0.070, P=0.1146\right.$; Fig. 4B). However, a highly signifi-
FIGURE 2. Sequential changes of chimerism (male DNA concentration) in recipient peripheral blood $(O$, samples with undetectable levels of male DNA). Both the frequency of detection and the concentrations of male DNA were significantly higher $(P<0.0001$, analysis of variance) in recipients with simultaneous donor bone marrow infusion (groups 2-7) than in those without infusion (group 1) at $7,14,21$, and 56 days after transplantation.
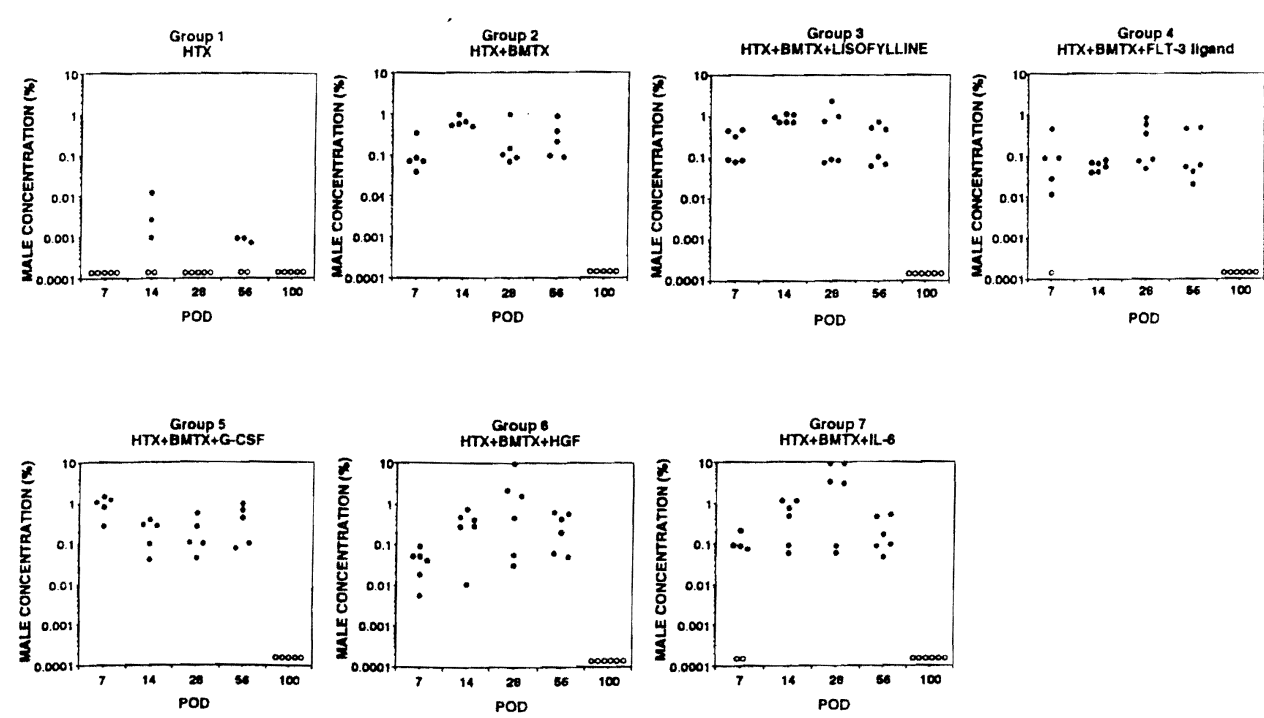

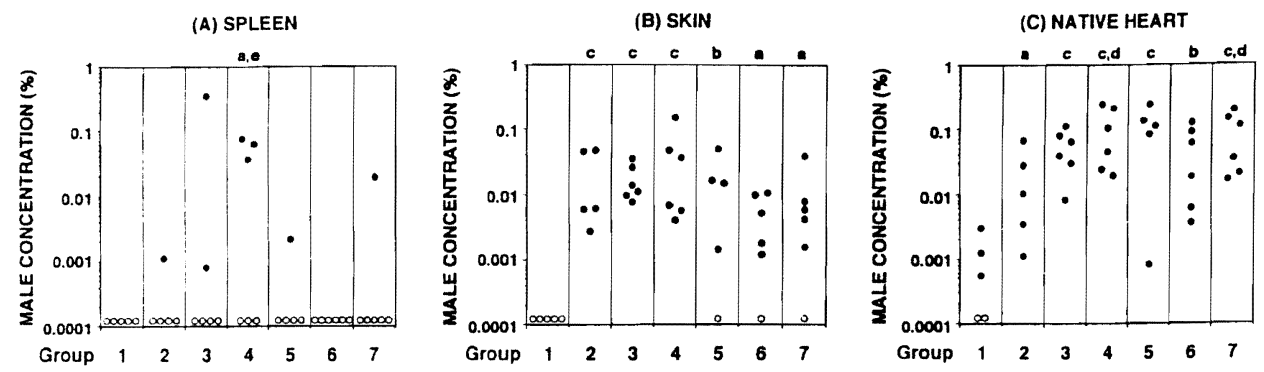

FIGURE 3. Systemic chimerism in re cipient (A) spleen, (B) skin, and (C) native heart at 100 days after transplan. tation $(\bigcirc$, samples with undetectable levels of male DNA). a: $P<0.01$ vs. group 1, b: $P<0.001$ vs. group 1, c: $P<0.0001$ vs. group 1 , d: $P<0.05$ vs. group 2, and e: $P<0.01$ vs. group 2 (analysis of variance).

TABLE 3. Comparison of severity of obliterative arteriopathy and overall inflammation in heart allografts at 100 days after transplantation ${ }^{a}$

\begin{tabular}{|c|c|c|c|c|c|c|c|}
\hline \multirow[b]{2}{*}{ Group } & \multirow[b]{2}{*}{ Transplantation } & \multirow[b]{2}{*}{ Growth factor } & \multirow[b]{2}{*}{$\mathrm{n}$} & \multicolumn{3}{|c|}{ Arterial changes } & \multirow{2}{*}{$\begin{array}{c}\text { Overall } \\
\text { inflammation } \\
\text { score }\end{array}$} \\
\hline & & & & $\begin{array}{c}\text { Total no. of } \\
\text { arteries } \\
\text { scored }\end{array}$ & $\begin{array}{l}\text { Average grade of } \\
\text { lesions }\end{array}$ & $\begin{array}{l}\text { Percent of arteries } \\
\text { with disease }(\%)\end{array}$ & \\
\hline 2 & $\mathrm{HTX}+\mathrm{BMTX}$ & None & 5 & 60 & $0.84 \pm 0.08$ & $47.16 \pm 8.44$ & $1.30 \pm 0.76^{b}$ \\
\hline 3 & $\mathrm{HTX}+\mathrm{BMTX}$ & Lisofylline & 5 & 48 & $1.42 \pm 0.50$ & $60.92 \pm 20.63$ & $1.20 \pm 0.57^{b}$ \\
\hline 4 & HTX + BMTX & Flt-3 ligand & 6 & 87 & $0.57 \pm 0.25$ & $43.08 \pm 16.39$ & $0.75 \pm 0.27^{c}$ \\
\hline 7 & HTX + BMTX & IL-6 & 6 & 86 & $0.44 \pm 0.23^{a}$ & $30.17 \pm 13.86^{a}$ & $0.92 \pm 0.59^{c}$ \\
\hline
\end{tabular}

${ }^{a} P$-value vs group 1: $a<0.05, b<0.01, c<0.001$.

cant inverse correlation was found between the levels of overall inflammation and chimerism $\left(R^{\wedge} 2=0.261, P=0.0012\right.$; Fig. 4C).

\section{DISCUSSION}

When microchimerism was discovered in long-surviving human organ recipients, two mechanisms of allograft acceptance were proposed $(7,8)$ : (1) reciprocal clonal exhaustion of the co-existing donor and recipient immunocyte populations, and (2) reduced organ graft immunogenicity of the transplanted organ due to depletion of its peripheralized passenger leukocytes. Bishop et al. $(19,20)$ reported experimental evidence confirming a role of acute clonal exhaustion, attributed by Qian et al. (21) to apoptosis. However, skeptics of the significance of persistent late microchimerism (22) have focused on the inconsistency with which donor leukocytes can be found in the blood (or limited tissue samples) from patients $(7-9,23-30)$ and animals $(31-34)$ bearing long-surviving organ allografts. Incomplete sampling (in some reports of blood only) in both the clinical and experimental studies is one possible explanation for wide discrepancies in the frequency of donor leukocyte detection.

It was evident in the current study that both the site and timing of sampling profoundly influenced the finding of chimerism. Blood chimerism in the heart recipients was detectable during the first 2 postoperative months in $139(89 \%)$ of the 156 samples, including $37(95 \%)$ of 39 at 56 days. By 100 days, at which time all of the heart allografts were still beating, all 39 blood samples were negative. When the animals were killed, however, tissue chimerism was detected in $37 / 39(95 \%)$ of the native hearts, $31 / 39(80 \%)$ of the skin biopsy specimens, and only $9 / 39(23 \%)$ of the spleens. A similar but less clear late pattern of localization in host nonlymphoid tissues has also been noted recently in a rat heart transplant model by Shirwan et al. (34).
The eventual dominance of microchimerism in the nonlymphoid compartment (Fig. 5), which has not been recognized before, extends the second originally proposed mechanism of graft acceptance, by immune indifference (i.e., loss of organ immunogenicity caused by depletion of the donor leukocytes from the allograft $[7,8])$. It is now clear that chronic survival of the peripheralized donor cells may depend in part on their confinement to nonlymphoid sites. In spite of their sequestration, we have suggested that they may be critical for maintenance of the clonal exhaustion (4) which, under circumstances of transplantation across an MHC barrier, is rarely if ever complete and nonreversible $(10,35,36)$. Periodic leakage of the "hidden" chimeric cells to lymphoid organs has been postulated to fill this maintenance role (4).

In this context, persistent chimerism, no matter whet its level, is only a necessary condition for, and is not synonymous with, graft acceptance or tolerance $(4,7,8,37)$. It follows that neither the development of rejection coincident with chimerism $(33,34,38-40)$ nor the inability to use chimerism to guide immunosuppressive drug weaning $(38,41)$ contravene the key role of microchimerism in allograft acceptance and tolerance (4). Although it has been argued that tolerance can be produced in the absence of donor hematopoietic cells $(31,32)$, the experiments prompting this conclusion may be experimental examples of "immune indifference" in which long survival of allografts does not confer donorspecific nonreactivity $(42-44)$.

In the studies reported herein, we determined whether there was a correlation between chronic rejection and the quantity and localization of early and late chimerism, using three different histopathologic end points: (1) percentage of arteries showing vasculopathy, (2) severity of the vascular lesions, and (3) overall inflammation score. By all three end points, chronic rejection was reduced in inverse proportion to the amount of detectable chimerism, which in turn was al- 

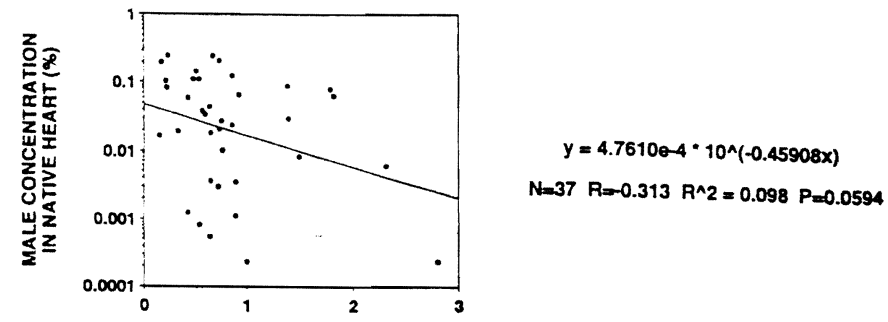

(A) A verage grade of arterial lesions

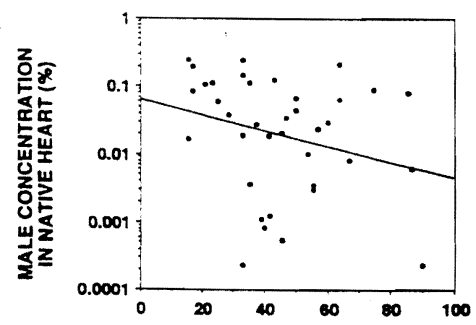

$y=6.4926 e-4 \cdot 10 \wedge(-1.1508 \theta-2 x)$ $N=37 R=-0.264 R^{\wedge} 2=0.070 \quad P=0.1146$ (B) Percentages of diseased arteries

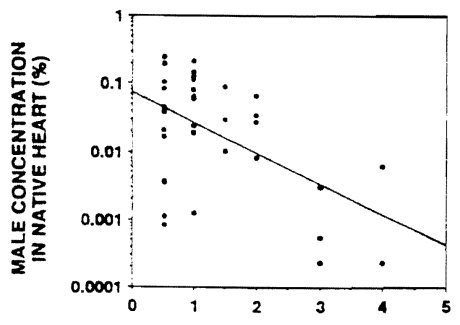

(C) Overall Inflammation $y=7.58110-4 * 10^{\wedge}(-0.44973 x)$

$N=37 R=0.511 R^{\wedge} 2=0.261 \quad P=0.0012$

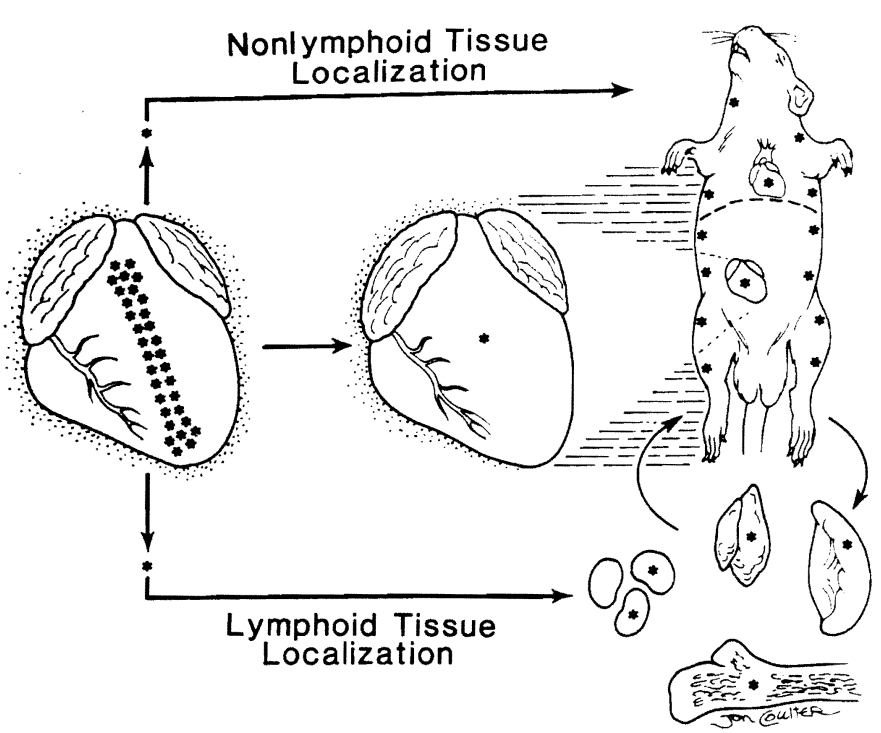

FIGURE 5. Reconstruction of events after organ transplantation, epitomized by the heart with its "passenger leukocyte" component depicted as a bone silhouette. Although these donor leukocytes are largely replaced by similar recipient cells, a small number $(<5 \%)$ remain donor cells. The eventual localization of the donor migratory cells is heavily represented in nonlymphoid tissues (skin and native heart shown here), from where they presumably leak to the lymphoid organs and maintain clonal exhaustion.

FIGURE 4. Correlation between histopathologic changes in heart allografts and chimerism levels (male DNA concentration) in native hearts. Hematoxylin and eosin samples were analyzed from the middle of heart allografts that were harvested 100 days after transplantation. Scattergrams demonstrate the correlation between the level of chimerism and (A) the average grade of arterial lesions, (B) percentages of diseased arteries, and $(C)$ overall inflammation. The linear regression for each group was the following: $A, R^{\wedge} 2=0.098$, $P=0.0594 ; \mathrm{B}, \mathrm{R}^{\wedge} 2=0.070, P=0.1146 ;$ and $\mathrm{C}, \mathrm{R}^{\wedge} 2=0.261, P=0.0012$.

ways greater in animals given adjunct bone marrow. This was statistically significant with the inflammation score, in accord with numerous previous reports of the protective effect of bone marrow (45-47).

Although the further advantage conferred by adding growth factor therapy postoperatively did not reach significance when compared with the protection of adjunct bone marrow alone, it can be concluded that none of the five tested molecules made chronic rejection worse. On the contrary, trends of reduced chronic rejection were seen with three of them (G-CSF, IL-6, and Flt-3 ligand), which suggests the need for further evaluation. Such investigations also can be justified by our previous demonstration that organ-based hematopoietic progenitor cells are increased by growth factors, such as G-CSF, that promote the growth and mobilization of hematolymphopoietic stem cells (see Table 1). G-CSF and granulocyte/macrophage CSF already have been widely used in clinical bone marrow transplant recipients and after cancer chemotherapy (48); similar trials with Flt-3 ligand are underway. The administration of G-CSF and granulocyte/ macrophage CSF long after transplantation to stable organ recipients has not increased the risk of either rejection or graft-versus-host disease (49-53).

In nonrandomized trials, Foster et al. (54) have reported a reduction in both infection and rejection in liver transplant recipients treated with G-CSF during the early postoperative period (54). Because these benefits have not been duplicated in multicenter randomized trials (J.W. Williams, personal communication, 1998), further preclinical laboratory studies under controlled circumstances will be doubly important.

Acknowledgments. We thank Drs. Toshiki Sakamoto, Zejin Liu, and Lianfu Wang for their helpful suggestions given during the course, of this study.

\section{REFERENCES}

1. Nemlander A, Soots A, Willebrand EV, Husberg B, Hayry P. Redistribution of renal allograft responding leukocytes during rejection. II. Kinetics and specificity. J Exp Med 1982; 156: 1087.

2. Larsen CP, Morris PJ, Austyn JM. Migration of dendritic leukocytes from cardiac allografts into host spleens: a novel route for initiation of rejection. J Exp Med 1990; 171: 307.

3. Demetris AJ, Qian S, Sun H, et al. Early events in liver allograft rejection: delineation of sites of simultaneous intragraft and recipient lymphoid tissue sensitization. Am J Pathol 1991; 138: 609.

4. Starzl TE, Zinkernagel $R$. The regulation of immune reactivity by antigen migration and localization: a comparison of "tolerance" to infectious agents and allografts. $N$ Engl $J$ Med (in press).

5. Murase N, Starzl TE, Ye Q, et al. Multilineage hematopoietic reconstitution of supralethally irradiated rats by syngeneic whole organ transplantation: with particular reference to the 
liver. Transplantation 1996; 61: 1.

6. Taniguchi H, Toyoshima T, Fukao K, Nakauchi H. Presence of hematopoietic stem cells in the adult liver. Nat Med 1996; 2: 198.

7. Starzl TE, Demetris AJ, Murase N, Ildstad S, Ricordi C, Trucco M. Cell migration, chimerism, and graft acceptance. Lancet 1992; 339: 1579.

8. Starzl TE, Demetris AJ, Trucco M, et al. Cell migration and chimerism after whole-organ transplantation: the basis of graft acceptance. Hepatology 1993; 17: 1127.

9. Starzl TE, Demetris AJ, Trucco M, et al. Chimerism after liver transplantation for type IV glycogen storage disease and type I Gaucher's disease. N Engl J Med 1993; 328: 745.

10. Murase N, Starzl TE, Tanabe M, et al. Variable chimerism, graft versus host disease, and tolerance after different kinds of cell and whole organ transplantation from Lewis to Brown-Norway rats. Transplantation 1995; 60: 158.

11. Demetris AJ, Murase N, Ye Q, et al. Analysis of chronic rejection and obliterative arteriopathy: possible contributions of donor antigen-presenting cells and lymphatic disruption. Am J Pathol 1997; 150(2): 563 .

12. Lyman SD, Brasel K, Rousseau AM, Williams DE. The flt3 ligand: a hematopoietic stem cell factor whose activities are distinct from steel factor. [Review]. Stem Cells 1994; 12 (suppl 1): 99 (discussion, 108).

13. Skelly SM, Tackney C, Hicklin D, et al. High-level expression of a biologically active human interleukin- 6 mutein. J Biotechnol 1994; 34: 79

14. Singer JW, Burstein SL, Rice GC, Gordon WP, Bianco JA. Inhibitors of intracellular phosphatidic acid production: novel therapeutics with broad clinical applications. Exp Opin Invest Drugs 1994; 3: 631.

15. Foster PF, Kociss K, Shen J, et al. Granulocyte colony-stimulating factor immunomodulation in the rat cardiac transplantation model. Transplantation 1996; 61: 1122

16. Murase N, Ye Q, Sakamoto T, et al. Effect in supralethally irradiated rats of granulocyte colony-stimulating factor and lisofylline on hematopoietic reconstitution by syngeneic bone marrow or whole organ passenger leukocytes. Transplantation 1997; 63: 1840 .

17. Blin N, Stafford DW. A general method for isolation of high molecular weight DNA from eukaryotes. Nucleic Acids Res 1976; 3: 2303.

18. Tashiro H, Fukuda Y, Kimura A, et al. Monitoring for rejection and engraftment by means of polymerase chain reaction after rat orthotopic liver transplantation. Transplantation 1994; 58: 745 .

19. Bishop GA, Sung J, Decruz DJ, et al. Tolerance to rat liver allografts. III. Donor cell migration and tolerance-associated production in peripheral lymphoid tissues. J Immunol 1996; 156: 4925.

20. Bishop AG, Sun J, Sheil AGR, McCaughan GW. High-dose/activation-associated tolerance. Transplantation 1997; 64: 1377.

21. Qian S, Lu L, Fu F, et al. Apoptosis within spontaneously accepted mouse liver allografts: evidence for deletion of cytotoxic $\mathrm{T}$ cells and implications for tolerance induction. J Immunol 1997; 158: 4654 .

22. Wood K, Sachs DH. Chimerism and transplantation tolerance: cause and effect. Immunol Today 1996; 17: 584.

23. Starzl TE, Demetris AJ, Trucco M, et al. Systemic chimerism in human female recipients of male livers. Lancet 1992; 340: 876.

24. Starzl TE, Demetris AJ, Trucco M, et al. Chimerism and donorspecific nonreactivity 27 to 29 years after kidney allotransplantation. Transplantation 1993; 55: 1272.

25. Suberbielle C, Caillat-Zucman S, Legendre C, et al. Peripheral microchimerism in long-term cadaveric kidney allograft recipients. Lancet 1994; 343: 1468.

26. Ishida H, Kawai T, Tanabe K, et al. Status of microchimerism in recipients 15 years after living related kidney transplantation. Transplantation 1996; 62: 126.

27. Elwood ET, Larsen CP, Maurer DH, et al. Microchimerism and rejection in clinical transplantation. Lancet 1997; 349: 1358.

28. Norris S, Lawler M, McCann S, Hegarty J, O'Farrelly C. Donor type microchimerism is an infrequent event following liver transplantation and is not associated with graft acceptance. Hepatology 1997; 26: 848.

29. Ricordi C, Karatzas T, Nery J, et al. High-dose donor bone marrow infusions to enhance allograft survival. Transplantation 1997; 63: 7 .

30. Jonsson JR, Hogan PG, Thoma R, et al. Peripheral blood chimerism following human liver transplantation. Hepatology 1997; 25: 1233.

31. Bushell A, Pearson TC, Morris PJ, Wood KJ. Donor-recipient microchimerism is not required for tolerance induction following recipient pretreatment with donor specific transfusion and anti-CD4 antibody. Transplantation 1995; 59: 1367.

32. Shirwan H, Wang HK, Barwari L, Makowka L, Cramer DV. Pretransplant injection of allograft recipients with donor blood or lymphocytes permits allograft tolerance without the presence of persistent donor microchimerism. Transplantation 1996; $61: 1382$

33. Frede SE, Levy AE, Alexander JW, Babcock GF. An examination of tissue chimerism in the ACI to Lewis rat cardiac transplant model. Transplant Immunol 1996; 4: 227.

34. Shirwan H, Wu GD, Barwari L, Liu A, Cramer DV. Induction of allograft nonresponsiveness after intrathymic inoculation with donor class I allopeptides. II. Evidence for persistent chronic rejection despite high levels of donor microchimerism. Transplantation 1997; 64: 1671 .

35. Murase N, Kim DG, Todo S, Cramer DV, Fung JJ, Starzl TE. FK 506 suppression of heart and liver allograft rejection. II: The induction of graft acceptance in rat. Transplantation 1990; 50: 739.

36. Qian S, Demetris AJ', Murase N, Rao AS, Fung JJ, Starzl TE. Murine liver allograft transplantation: tolerance and donor cell chimerism. Hepatology 1994; 19: 916.

37. Starzl TE, Demetris AJ, Murase N, Trucco M, Thomson AW, Rao AS. The lost chord: microchimerism. Immunol Today 1996; 17: 577.

38. Schlitt HJ, Hundrieser J, Ringe B, Pichlmayr R. Donor-type microchimerism associated with graft rejection eight years after liver transplantation. N Engl J Med 1994; 330: 646.

39. Molleston JP, Alevy YG, Sivasai KSR, Mohanakumar T, Howard TK. Evidence that pediatric liver transplant recipients may undergo late rejection episodes in spite of donor-specific microchimerism. Transplantation 1996; 61: 656.

40. Sivasai KSR, Alevy YG, Duffy BF, et al. Peripheral blood microchimerism in human liver and renal transplant recipients. Transplantation 1997; 64: 427.

41. Anand AC, Hubscher SG, Gunson BK, McMaster P, Neuberger JM. Timing, significance, and prognosis of late acute liver allograft rejection. Transplantation 1995; 60: 1098.

42. Talmage DW, Dart G, Radovich J, Lafferty KJ. Activation of transplant immunity: effect of donor leukocytes on thyroid allograft rejection. Science 1976; 191; 385.

43. Lafferty KJ, Prowse SJ, Simeonovic CJ. Immunobiology of tissue transplantation: a return to the passenger leukocyte concept. Annu Rev Immunol 1983; 1: 143

44. Starzl TE, Rao AS, Thomson AW, Murase N, Demetris AJ. Donor-recipient microchimerism and tolerance induction. Transplantation 1996; 61: 169.

45. Monaco AP, Wood ML. Studies on heterologous antilymphocyte serum in mice. VII. Optimal cellular antigen for induction of immunologic tolerance with antilymphocyte serum. Transplant Proc 1970; 2: 489.

46. Thomas J, Carver M, Foil B, Haisch C, Thomas F. Renal allo- 
graft tolerance induced with ATG and donor bone marrow in outbred rhesus monkeys. Transplantation 1983; 36: 104.

47. Barber WH, Mankin JA, Laskow DA, et al. Long-term results of a controlled prospective study with transfusion of donor-specific bone marrow in 57 cadaveric renal allograft recipients. Transplantation 1991; 51: 70 .

48. Lieschke GJ, Burgess AW. Granulocyte colony-stimulating factor and granulocyte-macrophage colony-stimulating factor (2). N Engl J Med 1992; 327(2): 99.

49. Kutsogiannis DJ, Crowther MA, Lazarovits AI. Granulocyte macrophage colony-stimulating factor for the therapy of cytomegalovirus and ganciclovir-induced leukopenia in a renal transplant recipient. Transplantation 1992; 53: 930.

50. Gordon MS, O'Donell JA, Mohler ER III, Cooper MA. The use of granulocyte colony-stimulating factor in the treatment of fever and neutropenia in a heart transplant patient. J Heart Lung Transplant 1993; 23: 1369.

51. Colquhoun SD, Shaked A, Jurim O, Colonna JO, Rosove MH,
Busuttil RW. Reversal of neutropenia with granulocyte colonystimulating factor without precipitating liver allograft rejection. Transplantation 1993; 56: 1593.

52. Patel HD, Anderson JR, Duncombe AS, Carrington D, Murday A. Granulocyte colony-stimulating factor: a new application for cytomegalovirus-induced neutropenia in cardiac allograft recipients. Transplantation 1994; 58: 863.

53. Peddi VR, Hariharan S, Schroeder TJ, First MR. Role of granulocyte colony stimulating factor (G-CSF) in reversing neutropenia in renal allograft recipients. Clin Transplant 1996; 10: 20.

54. Foster PF, Sankary HN, McChesney LP, et al. The use of granulocyte colony-stimulating factor after liver transplantation. Transplantation 1995; 59: 1557.

Received 15 January 1998.

Accepted 15 March 1998.

\title{
DIFFERENTIAL INHIBITION OF B-CELL DEVELOPMENT AND XENOREACTIVE NATURAL ANTIBODY PRODUCTION BY ADMINISTRATION OF ANTI- $\mu$ OR ANTI- $\delta$ MONOCLONAL ANTIBODIES IN ADULT RATS ${ }^{1}$
}

\author{
Miguel Soares, ${ }^{2}$ Xavier Havaux, Ronald Van Beneden, Isabel Kinet, Aziz A. Chentoufi, \\ Françoise Nisol, Françoise Cormont, Herve Bazin, ${ }^{3}$ and Dominique Latinne \\ Experimental Immunology Unit, Faculty of Medicine, University of Louvain, B-1200 Brussels, Belgium
}

Background. Given the role of xenoreactive natural antibodies (XNA) in the pathogenesis of xenograft rejection, we tested whether the administration of anti- $\mu$ or anti- $\delta$ monoclonal antibodies (mAbs) in adult rats would suppress the generation of XNA.

Methods. Adult LOU/C (Ig $\kappa-1$ a) rats were treated with anti- $\mu$ or anti- $\delta$ mAbs after nonlethal total body irradiation and bone marrow transplantation from congenic LOU/C (Ig $\kappa-1 b)$ rats. The differentiation of donor bone marrow (BM)-driven ${\operatorname{Ig} \kappa-1 b^{+}} B$ cells and XNA production were analyzed.

Results. Both anti- $\mu$ and anti- $\delta$ mAbs arrested B-cell differentiation in the $B M$. In anti- $\mu$-treated rats, there was a total depletion of donor-driven, peripheral Ig $\kappa$ $\mathrm{Ib}^{+} \mathrm{B}$ cells, secreting cells, and circulating XNA of the

${ }^{1}$ This work was supported in part by the Fonds National de la Recherche Scientifique (Belgium) and by a fellowship from IRSIA (Institut pour la Recherche Scientific Industrielle et Agicole, Belgium) awarded to M.S.

${ }^{2}$ Address correspondence to: Miguel Soares, $\mathrm{PhD}$, Center for Immunobiology, Beth Israel Deaconess Medical Center, Harvard Medical School, 99 Brookline Avenue, Boston, MA 02215. E-mail: MSOARES@bidmc.harvard.edu.

${ }^{3}$ H.B. is a staff member of the Commission of the European Communities, Biotechnology Division.
Ig $\kappa$-1b allotype. In anti- $\delta$-treated rats, a significant number of $\operatorname{Ig} \kappa-1 b^{+} B$ cells, which did not express membrane IgD, "escaped" deletion and partially repopulated peripheral lymphoid organs. This B-cell population was active in the production of XNA, as revealed by the high serum levels of XNA in these animals.

Conclusions. Anti- $\mu$ administration resulted in arrest of B-cell differentiation and in down-regulation of IgM and IgG XNA production in adult rats. These data suggest that the use of anti- $\mu$ mAbs may be a useful approach to suppress the production of XNA and prevent xenograft rejection. Furthermore, we suggest that the B-cell population responsible for the production of XNA in adult rats belongs to a B-cell lineage expressing low levels of membrane IgD and "escaping" deletion in the BM upon anti- $\delta$ treatment.

The xenotransplantation of immediately vascularized organs from pigs to humans is perceived as a potential solution to overcome the current organ donor shortage in clinical transplantation (1). The success of this approach remains limited due to the occurrence of hyperacute or delayed xenograft rejection. Humans and Old World primates have high serum levels of preformed IgM and IgG xenoreactive natural 